\title{
Motivation and Job Satisfaction of Tutors in Colleges of Education in the Central Region of Ghana
}

\author{
Josephine Aba Entsiwah \\ OLA College of Education, Social Sciences Department, Cape Coast, Ghana
}

\begin{abstract}
The study sought to examine the present disposition of the tutors of the colleges of education, with regard to their present and future job motivation and satisfaction. The research design for the study is a crosssectional survey design. The population of the study was all the academic staff of three Colleges of Education namely, OLA College of Education, Fosu College of Education and Komenda College of Education. OLA College of Education has 58 tutors, Komenda College of Education has 42 tutors and Fosu College of Education has 52 tutors. The total population of all the three colleges summed up to 152 tutors. The sample for the study was made up of all the 152 tutors in the three colleges of education. The sampling technique used was census. The main data collection instrument was questionnaire and interview. The results of the study indicate that tutors of colleges of education in the central region had high career expectations. The study also revealed that human resource policies, reward systems, incentives available to tutors and the roles played by tutor associations do exist in colleges of education in the central region of Ghana. The human resource policies ensured staff welfare, job security, promote opportunities for training and ensure good working conditions. This policy has however not generally been able to provide tutors with the required motivation they need to effectively carry out their duties. It was recommended that tutor associations should work more assiduously to ensure that the welfare of the members are respected and taken into due consideration by the college administration to ensure that tutors are motivated well enough to carry out their responsibilities.
\end{abstract}

Keywords: Motivation, Job Satisfaction, Tutor Associations.

\section{Introduction}

Organizations exist because there are human beings who direct their existence. It is important to remember, however, that individuals are only assets in so far as they choose to invest knowledge and skills that benefit their organizations. This implies that, in a nation or an organizational setup, the most important of all the resources (assets) is the human resources. This partly accounts for the current interest in Human Resource Accounting (HRA), given that apart from it being important, it is also the most expensive and difficult to retain. Utuka (2001) echoing what has been alluded to, earlier by Schultz (1980) noted that human capital is an important input and forms the basis for wealth creation. It is the active agent of production who accumulate capital, exploit natural resources, build and develop social, political and economic organizations, and plan national development programmes. Countries must therefore develop the skills and knowledge of their people and utilize them effectively in order for the nation to develop. This brings to the fore the importance of education. Research evidence indicates that, for human capital to spawn perceptible impact on economic development, a nation needs to have a minimum critical mass of at least 70 percent or more literate population. This is evidenced by the fact that, at the time of Ghana's independence, countries that invested heavily in education have higher per capita income now than countries that did not. At the core of a nation's human capital formation is the teacher. Although modern infrastructural facilities are essential in educational institutions, it is largely the work of the teacher that determines the degree of success or failure in the institution's effort to contribute towards the achievement of national educational development goals.

It is the teacher who gives the institution its credibility and determines its character. The teacher is the vehicle through which knowledge is generated and skills developed. Therefore, the role of the teacher in human capital formation is very critical and therefore whatever is required to boost the morale and retain 
teachers in our educational institutions is of paramount importance. Recognizing that, the teacher is both an embodiment of human capital and also the channel through which the human resource of a nation is developed. The relevance of job satisfaction and motivation are therefore very serious to the long-term growth and development of any educational system. They probably rank alongside professional knowledge and skills, core competencies, educational resources and strategies as the veritable determinants of an educational system's success and performance. Professional knowledge, skills and core competencies occur when one feels effective in one's behaviour. Professional knowledge, skills and competencies can be seen when one is taking on and mastering challenging tasks directed at educational success and performance (Filak and Sheldon, 2003).

The above factors are closely similar to efficacy, and, it is well known that many teachers lose or fail to develop self-efficacy within educational settings (Dweck, 1999). In addition, needs satisfaction and motivation to work cannot be over emphasize and are very essential in the lives of teachers because they form the fundamental reason for working in life. While almost every teacher works in order to satisfy his or her needs in life, job satisfaction in this context is the ability of the teaching profession or job to meet teachers' needs and improve their job/teaching performance. Interest in job motivation and satisfaction has attracted attention in recent years. For decades, researchers have been concerned with the job satisfaction, job performance relationship. The implicit assumption guiding this research has been that a happy worker is a productive worker. Research on the topic of job satisfaction has been conducted in the past 65 years (Koutelios, 2001). It is estimated that there are over 5000 studies of job satisfaction which have been published as at 1992. Much of these researches have been based on the explicit assumptions that the lack of job satisfaction is a potential determinant of absenteeism, high labour turnover, in-role job performance and extra-role behaviours and also that, the primary antecedents of job attitude are within management ability to influence.

Teachers in Ghana as elsewhere are expected to render a very high job performance, and the Ministry of Education (MOE) is always curious regarding the job performance of its teachers. Also, the Ministry of Education demands a very high measure of loyalty, patriotism, dedication, hard work and commitment from its teachers (Ubom and Joshua, 2004). Similarly, the roles and context of educations' motivational methods and tools cannot be over emphasized because high motivation enhances productivity which is naturally in the interests of all educational systems (Ololube, 2004, 2005). This explains why nations and organizations have become interested in motivation which leads to job satisfaction of their employees with the view to retain, maintain and utilize them to the best of their abilities. Most research on teachers in Ghana has concentrated on the recruitment of teachers and how it affects retention (Utuka 2001; Asmah, 1999), without examining what teachers are looking for in their work. According to Ingersoll (2001) recruitment programs would not solve staffing problems in schools; instead, the organizational causes of low teacher retention should be considered. One factor driving the need to support teachers is the critical and growing shortage of professional staff in public schools. Equally worrying is that, teachers new to the profession continue to leave in large numbers. Available evidence show that, up to, 30 percent of new teachers posted in more deprived districts leave within the first 5 years in the USA (Darling-Hammond, 2001).

Data on Ghana's situation is not readily available, but the attrition rate of teachers may not be different if not worse. For example, a study on causes and consequences of teacher attrition in Senior High Schools (SHS) in the Greater Accra Region, it was discovered that 88 percent of the respondents $(94 \%$ males and $86 \%$ female teachers) indicated their intention to leave the teaching profession (Spio, 1999). Given these statistics, the necessity for retaining teachers, particularly in critical areas, is evident In a study conducted by Ingersoll (2001), that specifically examined employee dissatisfaction in both public and private school, it was discovered that "school staffing problems are not primarily due to teacher shortages but to excessive demands resulting from a 'revolving door' where large numbers of qualified teachers depart their jobs for reasons other than retirement". Ingersoll (2001) notes, as do Maslach and Leiter (1997), that previous data on job dissatisfaction and turnover had centered on the individual. Viewing the school as an organization, Ingersoll argues that there are characteristics and conditions that have been overlooked or discounted in previous research. He finds four factors, including insufficient support from school administration; discipline problems with students; insufficient participation in school-wide decision-making; and low salary to be of equal cause for both the migration of teachers between schools and in their actual leaving of the 
profession. The evidence worldwide suggests that a lot of research has been done on job satisfaction in the business sector, a few in the educational sector, especially on teachers (Oshagbemi, 2003), hence, the need for research on teachers' motivation and job satisfaction.

\section{Statement of the Problem}

The 46 public colleges of education in Ghana have all been upgraded to the tertiary status. This means that tutors in these colleges are to enjoy incentives and remuneration comparable to other tertiary institutions in Ghana. However, there are still some issues of job satisfaction and motivation as far as the tutors of the colleges of education in Ghana are concern. This has necessitated the need to examine the present disposition of the tutors of the colleges of education, with regard to their present and future job motivation and satisfaction.

\section{Purpose of the Study}

The study sought to examine the present disposition of the tutors of the colleges of education, with regard to their present and future job motivation and satisfaction.

\section{Research Questions}

The study was guided by the following research questions;

1. What are the career expectations of tutors of the three colleges of education?

2. What are the sources of job motivation and satisfaction of tutors in the colleges of education in Ghana?

\section{Methodology}

The research design for the study is a cross-sectional survey design. The population of the study was all the academic staff of three Colleges of Education namely, OLA College of Education, Fosu College of Education and Komenda College of Education. OLA College of Education has 58 tutors, Komenda College of Education has 42 tutors and Fosu College of Education has 52 tutors. The total population of all the three colleges summed up to 152 tutors. The sample for the study was made up of all the 152 tutors in the three colleges of education. The sampling technique used was census. The main data collection instrument was questionnaire and interview. The qualitative data was analyzed by transcription of the responses manually. The quantitative data was analyzed using frequencies.

\section{Results and Discussion}

What are the career expectations of tutors of the three colleges of education? This research question explored respondents' view about their career expectation. The result of the career expectations of tutors of the three colleges of education is presented in table 1.

\section{Table 1: Career Expectations of Respondents}

\begin{tabular}{|l|l|l|l|}
\hline Career Expectation & Most important & Important & Not important \\
\hline Cooperation with colleagues & $119(83.8)$ & $\mathbf{N}(\%)$ & $\mathbf{N}(\%)$ \\
\hline Full utilization of skills & $128(90.1)$ & $23(16.2)$ & $0(0.0)$ \\
\hline $\begin{array}{l}\text { Career job description and } \\
\text { responsibility }\end{array}$ & $99(69.90)$ & $14(9.9)$ & $0(0.0)$ \\
\hline Opportunity for training & $105(73.9)$ & $33(23.2)$ & $10(7.0)$ \\
\hline $\begin{array}{l}\text { Opportunity to earn high } \\
\text { salary and allowance }\end{array}$ & $129(90.80)$ & $26(18.3)$ & $0(0.0)$ \\
\hline Job Security & $116(81.7)$ & $26(18.3)$ & $0(0.0)$ \\
\hline Challenging job & $32(22.5)$ & $110(77.5)$ & $0(0.0)$ \\
\hline Staff Welfare & $109(76.8)$ & $33(23.2)$ & $0(0.0)$ \\
\hline
\end{tabular}




\begin{tabular}{|l|l|l|l|}
\hline Good working conditions & $122(85.90)$ & $20(14.1)$ & $0(0.0)$ \\
\hline Respect in society & $140(98.6)$ & $2(1.4)$ & $0(0.0)$ \\
\hline $\begin{array}{l}\text { Recognition for good work } \\
\text { done }\end{array}$ & $135(95.1)$ & $7(4.7)$ & $0(0.0)$ \\
\hline Personal freedom on the job & $127(89.4)$ & $15(10.6)$ & $0(0.0)$ \\
\hline
\end{tabular}

Results from table 1 shows that majority $(83.8 \%)$ of the tutors expect cooperation from their colleagues in the college and was important to them. In the same way, $90.1 \%$ of the tutors believed that their expectation was to utilise their skills fully. The study also revealed that majority of the respondents was of the view that opportunity for training was very important expectation to them. It can therefore be deduced from the table 1 that all the career expectations were important to tutors of the three colleges of education

RQ2. What are the sources of job motivation and satisfaction of tutors in the colleges of education in Ghana? This research question sought to find out the sources of job motivation and satisfaction in the colleges of education in Ghana. The interview conducted revealed four thematic areas as the sources of job motivation and satisfaction of tutors in the colleges of education in Ghana. These are human resource policies of the colleges, reward systems of the colleges, incentives available to tutors at the colleges and the roles played by tutor associations.

On the human resource policies of the colleges, the respondents indicated that there are human resource policies in their respective colleges. These policies according to them are meant among other things, to; ensure staff welfare, job security, promote opportunities for training and ensure good working conditions. They however argued that the policies have not generally been able to provide them with the required motivation they need to effectively carry out their duties. One respondent said that "there is a policy in the college that seeks to ensure the welfare of the tutors as well as other staff. The policy has however not been able to adequately cater for our welfare".

On reward systems of the college, the tutors indicated that even though they give off their best in terms of productivity, their efforts were not adequately being recognized for any reward in the form of scholarships for further studies. Their responses is summed up by one of the tutors as "sometimes you give all you can in terms of teaching, however, nobody recognizes what you do. They rather feel you do not give off your best". The responses from the tutors are consistent with Vroom (1964) assertion that people's reports of their satisfaction with their jobs are directly related to the extent to which their jobs provide them with rewarding outcomes.

With regards to the incentives available to the college of education tutors, few of the respondents indicated that they are sometimes given scholarships for further studies and rent allowances in order to reduce the financial expenditure as well as accommodation problems. However, majority of the tutors indicated that there are incentives available in the colleges but they are not accessible due to the institutional bottle-necks in the colleges. For instance, one of the respondent said that "they would tell you that they would give you scholarships and other things but they do not give you anything when the time comes".

With regards to the roles played by tutor associations, majority of the tutors indicated that their associations really play several roles in ensuring their welfare and sustenance in their respective schools. This is one respondent response "our association makes sure that we are treated well by the college. The association also ensure that our working rights are safeguarded and not infringed upon by the college in terms of our salaries and allowances. The association is however not usually able to negotiate high salaries for us".

\section{Summary of Key Findings}

The results of the study revealed the various key findings.

1. Tutors of colleges of education in the central region had high career expectations which included good opportunities for training, clear job description and responsibility, full utilization of skills, effective cooperation with colleagues, realistic opportunity to earn high salaries and allowances, adequate job security, effective staff welfare, good working conditions, respect in society, personal 
freedom on the job and recognition for good work done. These expectations as found by the study are very important to the tutors in achieving their self-actualization needs.

2. The study also revealed that human resource policies, reward systems, incentives available to tutors and the roles played by tutor associations do exist in colleges of education in the central region of Ghana. The human resource policies ensured staff welfare, job security, promote opportunities for training and ensure good working conditions. This policy has however not generally been able to provide tutors with the required motivation they need to effectively carry out their duties.

3. The associations in the colleges of education in Ghana play various important roles to ensure the welfare of their members. They are however unable to adequately advocate the needs of their members especially with regards to increased salaries and allowances. Reward systems of colleges of education are usually not motivating to the tutors enough.

\section{Conclusions}

It was concluded from the results of the study that tutors in the colleges of education in the central region of Ghana have a high career expectations which included good opportunities for training, clear job description and responsibility, full utilization of skills, effective cooperation with colleagues, realistic opportunity to earn high salaries and allowances, adequate job security, effective staff welfare, good working conditions, respect in society, personal freedom on the job and recognition for good work done.

It was also concluded that the sources of job motivation and satisfaction of tutors in the colleges of education in Ghana include human resource policies of the colleges, reward systems of the colleges, incentives available to tutors at the colleges and the roles played by tutor associations.

\section{Recommendations}

1. Tutor associations should work more assiduously to ensure that the welfare of the members are respected and taken into due consideration by the college administration to ensure that tutors are motivated well enough to carry out their responsibilities.

2. There should be an upward adjustment of the salaries and allowances of tutors by government to motivate them to effectively perform their academic duties.

3. More opportunities in the form of scholarships should be made available to tutors by the college to provide the tutors with good opportunities for further training.

\section{Reference}

[1.] Asmah, E.A.M. (1999). How to hold the people you want to keep: An analysis of the recruitment and retention of senior administration personnel of the University of Cape Coast. Cape Coast:

M.A. thesis, IEPA, University of Cape Coast.

[2.] Darling-Hammond, L. (2001). The challenge of staffing our schools. Educational Leadership, 60, (8), 7-13.

[3.] Dweck, C. S. (1999). Self-theories: Their role in motivation, personality, and development. Philadelphia, PA: Psychology Press.

[4.] Filak, V. F, \& Sheldon, K. M. (2003). Student psychological need satisfaction and college teacherCourse evaluations, Educational Psychology, 23 (3), pp. 235-247.

[5.] Ingersoll, R.M. (2001). Teacher turnover and teacher shortages: An organizational analysis. Ame. Edu. Res. J. 38: 499-534.

[6.] Koustelios, A. D. (2001). Personal characteristics and job satisfaction of Greek teachers. The Int. J.Edu. Manag. Vol. 15, No 4, pp 7.

[7.] Maslach, C., \& Leiter, P. (1997). Burnout: The cost of caring. New York: Prentice Hall Press.

[8.] Ololube, N.P. (2004). Teachers job satisfaction and motivation for school effectiveness: An assessment. Helsinki: University of Helsinki, Finland.

[9.] Ololube, N.P. (2005). Benchmarking the motivational competencies of academically qualified teachers and professionally qualified teachers in Nigerian secondary schools. The African Symposium, Vol. 5, No. 3. pp. 17-37.

[10.] Oshagbemi, T. (2003). Personal correlates of job satisfaction: Empirical evidence from UK Universities. Int. J. Soc. Econ. 30:1210-1232. 
[11.] Schultz, D.P., \& Schultz, S.E. (1980). Psychology \& work today: An introduction to industrial and organizational psychology. New York: Prentice Hall.

[12.] Spio, S.Y. (1999). High labour turnover among graduate teachers:Causes and solution. A dissertation presented to the School of Administration, University of Ghana, for award of MBA.

[13.] Ubom, I. U., \& Joshua, M.T. (2004). Needs satisfaction variables as predictors of job satisfaction of employees: Implication for guidance and counselling. Edu. Res. J. Vol. 4. No. 3.

[14.] Utuka, U.G. (2001). Factors influencing recruitment and retention of teachers in the newly established senior secondary schools in the Ashanti Region of Ghana. M.Phil thesis. Cape Coast: Faculty of Education, University of Cape Coast. 